Revue d'histoire de l'Amérique française

REVUE D.HISTOIRE DE L'AMÉRIQUE FRANÇAISE

\title{
A Mirage: The Sea of the West (Part I) \\ Jean Delanglez
}

Volume 1, numéro 3, décembre 1947

URI : https://id.erudit.org/iderudit/801386ar

DOI : https://doi.org/10.7202/801386ar

Aller au sommaire du numéro

Éditeur(s)

Institut d'histoire de l'Amérique française

ISSN

0035-2357 (imprimé)

1492-1383 (numérique)

Découvrir la revue

Citer cet article

Delanglez, J. (1947). A Mirage: The Sea of the West (Part I). Revue d'histoire de l'Amérique française, 1(3), 346-381. https://doi.org/10.7202/801386ar d'utilisation que vous pouvez consulter en ligne.

https://apropos.erudit.org/fr/usagers/politique-dutilisation/ 


\section{A MIRAGE: THE SEA OF THE WEST}

\section{PART I}

When Columbus returned from his first voyage, everybody, himself included, thought that the newly discovered regions were islands off the coast of Asia, the land of silk and spices. When men realized the nature of the obstacle to the Far East ${ }^{1}$, a search for a short cut was begun, first by way of the northwest, and then by way of rivers and lakes across the continent. In this article the endeavors of the English are only incidentally touched upon, for we are mostly concerned with the efforts made by the French to find a transcontinental route to the Pacific. In the following pages we shall first ascertain the origin of the concept that west of the American Continent and in the middle latitudes there was a sea which opened on the Pacific Ocean; and second, we shall trace the evolution of this geographical conception until 1720, until the year when Charlevoix was commissioned by the French government to find the route to that elusive sea, which for more than a century had been receding farther west.

The first voyage sponsored by the French government to find a direct route to China is that of Giovanni Verrazano. In his report to Francis I of July 8, 1524, the Florentine explorer wrote as follows: " My intention in this voyage was to reach Cathay, on the extreme coast of Asia, expecting however, to find in the newly discovered land some such obstacle as they [the lands of the North American Con-

1. When Columbus was at the mouth of the Orinoco in August 1498, the volume of water pouring into the sea did not impress him as it did the sailors who accompanied the Corte Reals. When these sailors saw the mouths of the great rivers in the north, they concluded that " assurément, une île ne saurait en contenir un si grand nombre et de si considérables. " Pietro Paqualigo to his brother, Lisbon, October 19, 1501, in Paesi Novemente retrovati (Vicenza 1507), c.cxxvii, translated in H. H ARRISSE, Les Corte-Real et leurs voyages au Nouveau-Monde (Paris 1883), $49 \mathrm{ff}$. 
tinent] have proved to be, yet I did not doubt that I should penetrate by some passage to the eastern ocean. ") ${ }^{2}$

The earliest explicit mention of a sea in the West is on the map which Verrazano's brother, Hieronimo, drew in $1529^{3}$. The map shows "Verrazana siue Noua Gallia " connected with another section of North America by a narrow ithsmus next to which is the following inscription: « Da queste mare orientale [the Altantic Ocean] Si uede il mare occidentale fano 6 miglia di terra infra 1 uno et l'altro. ")

When Verrazano returned, Francis I was engaged in one of his numerous wars with Charles V, and ten years elapsed before the King of France again directed his attention to America. That besides searching for gold "et autres riches choses, " 4 Cartier's objective was also to find a water route to the Far East is clear from the permission of Admiral Philippe de Chabot authorizing Cartier to equip ships " pour voyager, découvrir et conquérir à Neuve-France, ainsi que trouver, par le Nord, la passage au Cathay ${ }^{5}$. " The relation of Cartier's first voyage show that these instructions were faithfully carried out.

After reaching the east coast of Newfoundland, Cartier moved north and entered the Strait of Belle Isle, which he called " La baye Chasteaulx. ") He then sailed to the western shore of Newfoundland,

2. Verrazano to Francis I, July 8, 1524, in H. C. MURPHy, The Voyage of Verrazano (New York 1875), Appendix VI, p. 184.

3. The map bears the inscription "Hyeronimus de Verraxano faciebat." A photographic reproduction, actual size, of the original is in E. L. STEvenson, Maps Illustrating Early Discovery and Exploration of America (1502-1530) (New Brunswick, N. J., 1906), no. 12. A good reproduction of North America is in C. O. PAULLIN, Atlas of the Historical Geography of the United States (New York 1932), pl. XIII. We say " explicit " mention of a Sea of the West, because on the Magiollo map of 1527 , there is also a narrow isthmus connecting the same two sections of North America; on this map, however, the sea to the west is called "Mare Indicum ". The whole map is reproduced in Stevenson, op. cit., no. 10, the Western Hemisphere in $\mathrm{H}$. HARRIsse, The Discovery of North America (Paris 1892), between pp. 216-217; North and Central America in K. KRETs ChMER, Die Entdeckung Amerika's in ihrer Bedeutung fuer die Geschichte des Weltbildes (text and atlas, Berlin 1892), atlas, Taf. XIV, no. 7. The Maggiolo and the Verrazano maps as well as those of the Dieppe school were all made on a common prototype now lost. Cf. H. HARRISSE, "La cartographie verrazanienne, "Revue de géographie (November 1896): 324-328.

4. H. P. Biggar, A Collection of Documents relating to Jacques Cartier and the Sieur de Roberval (Ottawa 1930), 42.

5. Charles De LA Ronciène, Jacques Cartier et la decouverte de la Nouvelle-France. (Paris 1931), 38. La Roncière does not indicate his source for this statement. 
across the Gulf of St-Lawrence to Prince Edward Island and New Brunswick, and north again constantly looking for a westward passage. Until he saw the extent of Chaleur Bay, he thought that it was the passage so much desired. "Le cap de ladite terre du Su [scl. the south shore of Chaleur Bay] fut nommé cap d'Espérance [Point Miscou] pour l'espoir que nous abuions de y trouuer passaige. $1{ }^{6}$ As Gaspé Bay seems just as little promising, Cartier sailed toward Anticosti Island, and after rounding "Cap St. Loys [East Cape "], he enterred the Canadian Channel which " pour ce que le jour SaintPierre [St. Peter in Chains, August 1] nous entrasmes dedans ledit destroit, nous le nommasmes le destroyt Saint-Pierre ${ }^{7}$. " He then made for the north shore of the St. Lawrence " pour veoyr si c'estoit baye ou passage. " When his search proved fruitless, Cartier assembled " tous les cappitaines, pillottes, mestres et compagnons pour auoyr l'oppinion et aduys de ce qu'il estoit bon de faire... après lesquelles oppinions prinses, fismes arivez large à nous en retourner. " ${ }^{8}$

When Cartier was at the mouth of the St. Lawrence at the time of this second voyage, he made the following observations:

Il y a entre les terres du Su \& celles du Nort, enuiron trente lieues, $\&$ plus de deux cens brasses de perfond \& nous ont lesdictz sauuaiges certiffié estre le chemin et cômencement du grât Silenne de Hochelaga ${ }^{\circ}$ \& chemin de Canada: lequel alloit tousiours en estroissent iusques à Canada: puis q l'on treuue l'aue doulce qui va si loing que iamais hôme n'auroit esté iusques au bout qu'ilz eussent ouy, \& que autre passaige n'y auoit que par bateaulx. Et voyant leur dire \& qu'ilz affermoient n'y auoir autre passaige, ne voulut led cappitaine passer oultre iusques a auoir veu le reste de ladicte terre \& coste deuers le Nort, qu'il obmis veoir depuis la Baye sainct Laurens pour aller veoir s'il y auoit aucun passaige ${ }^{10}$.

Now that Cartier was certain that there was not any passage in this region, he decided to "faire le chemin vers Canada. " With some of his men he went to Hochelaga, where from the summit of

6. H. Michelant, and A. Rame, eds., Relation originale de Jacques Cartier au Canada en 1534 (Paris 1867), 48.

7. Ibid., 48.

8. Ibid., 47.

9. On this expression see J. P. BAXTER, A Memoir of Jacques Cartier (New York 1906), 136, note 2 .

10. Brief recit, \& succincte narration, de la nauigation faicte es ysles de Canada, Hochelaga \& Saguenay... (Paris 1545), 9v. 
Mount Royal, " nous eusmes veue \& côgnoissance de plus de trente lieues a lenuiron d'icelle. " ${ }^{11}$ From the natives' description of the country beyond, Cartier must have realized that the St. Lawrence would not be a practical, and was certainly not a short passage to the Pacific.

The purpose of Cartier's third voyage to Canada was not to find a passage to the Far East, but to begin colonizing the country he had discovered and explored previously. Nor is there any mention of finding a passage in the letters patent granted to Roberval ${ }^{12}$. Jean Alfonce, however, Roberval's pilot, thought that the Saguenay might be the sought for passage.

Et est l'entrée dudict Saguenay à quarente et huyt et un tiers de dégré de la haulteur du polle arctique, et ladicte entrée n'a point plus de largeur que ung quart de lieue. Et est ladicte entrée dangereuse devers le surouest. Et au dedans de l'entrée, environ deux ou trois lieues, commence à eslargir, et semble que ce soit ung bras de mer, pour raison de quoy j'estime que ceste mer va à la mer Paciffique ou bien à la mer du Cattay. Et faict ung grand courant lequel fait un terrible ratz $^{13}$.

Later in his book, Alfonce expresses the opinion that there might be a passage farther south on the east coast of North America.

Les terres tirant vers Ochélaga sont beaucoup meilleures et plus chaudes que celles de Canada. ...... Ces terres tiennent à la Tartarie, et pense que ce soit le bout de l'Azie selon la rondeur du monde. Et pour ce il seroit bon avoir ung navire petit, de soixante et dix tonneaulx, pour la coste de la Fleuride ${ }^{14}$. Car j'ay esté en une baye jusques à quarente et deux degrez $^{15}$ entre Norombègue et la Fleuride mais n'ay pas veu du tout le fond, et ne sçay s'il passe plus avant. ${ }^{16}$

Beginning with the voyage of John Cabot and until well into the sixteenth century, the English sent expeditions to discover, in

11. Ibid., 27.

12. H. HARRISSE, Notes pour servir d l'histoire, d la bibliographie et à la cartographie de la Nouvelle-France et des pays adjacents 1545-1700 (Paris 1872), $243 \mathrm{ff}$.

13. J. Fontene au dit Alfonce de SaIntonge, La Cosmographie avec l'Espère et le Régime du Soleil et du Nord, G. Musset, ed. (Paris 1904), 489.

14. Not the Floridan peninsula, but today's southeastern United States.

15. Boston, on Massachusetts Bay, lies in latitude $42^{\circ} 30^{\prime}$.

16. Alfonce, op. cit., 496. 
the higher latitudes, the northwest passage to the Pacific. In 1585, however, the year after Sir Walter Raleigh received his charter for colonizing Virginia, Ralph Lane, who had been left in command at Roanoke Island, having heard that the headwaters of the Roanoke River were near the sea, set out to investigate the truth of the report. The source of the Roanoke was not found, but in his letter to Hakluyt, Lane quotes Thomas Harriot's opinion that « this river either riseth from the bay of Mexico, or els from very neere unto the same that . openeth out into the South Sea ${ }^{17}$. ") During these years, the colonists on the Atlantic seaboard were hearing news of large bodies of water located to the north or to the west, depending on the situation of the colony, which, they concluded " cannot be any other than the Southern Ocean, reaching to the regions of China, which unquestionably cannot be far from these parts. ") 18

The English acted on the belief that a river or rivers could be ascended to their headwaters, situated near a sea in the west, and these headwaters would be near the sources of rivers flowing westward. The main argument, which we shall later meet again and again in the writings of the French, is found in a passage of Edward Hayes' treatise published in 1602. Just as the St. Lawrence and other known rivers, he says, " doe descend from the highest parts or mountains, or middle of that continent [America], into our North sea [the Atlantic Ocean]. And like as those mountains doe cast from them, streames into our North sea; euen so the like they doe into the South sea, which is on the backe of that continent.

For all mountaines haue their descents toward the seas about them,... and waters... descending naturally, doe alwaies resort unto the seas inuironing those lands. $"{ }^{19}$.

17. R. HakLUYt, The Principal Navigations Voyages Traffiques \& Discoveries of the English Nation (12 vols., Glasgow reprint 1903-1095 of the second [1598-1600] edition), 8: 332 .

18. A. Brown, The Genesis of the United States (2 vols., Boston and New York 1890), 1: 146.

19. J. BRereton, A Briefe and true Relation of the Discouerie of the Nort part of Virginia... Whereunto is annexed a Treatise, of $M$. Edward Hayes, conteining important inducements for the planting in those parts, and finding a passage that way to the South sea, and China (London 1602), 22. 
Such was also the opinion of the man (Richard Hakluyt?) who drew up the instructions given to Newport and Gosnold, and who, to make his meaning clearer, used the following analogy:

You must observe if you can, whether the river on which you plant [i.e. establish settlements] doth spring out of mountains or out of lakes. If it be out of any lake, the passage to the other sea will be more easy, and [it] is like enough, that out of the same lake you shall find some spring which run[s] the contrary way towards the East India Sea; for the great and famous rivers of Volga, Tan[a]is [Don] and Dwina have there heads near joyn $[e] \mathrm{d}^{20}$; and yet the one falleth into the Caspian Sea, the other into the Euxine [Black] Sea, and the third into the Poelonian [White] Sea. ${ }^{21}$

The only tangible result of the explorations of Captain John Smith up Chesapeake Bay, up the James and the Potomac rivers, was the " good hope we had by the Salvages relation, that our Bay had streched into the south Sea, or somewhat neare it ${ }^{22}$." Behind all the voyages undertaken in Virginia to find the Sea of the South was the firm belief that the headwaters of the rivers flowing into the Atlantic from the Appalachians were near the headwaters of rivers flowing westward into the Pacific.

As we have seen, when Verrazano returned from his voyage the conditions in France were not conducive to act upon the information brought back by the Florentine navigator. The work of Jacques Cartier and Roberval was not continued for the same reason: Francis I was again at war with Charles V, and his successor Henri II continued the struggle. In 1562, two years after Charles IX ascended the throne, the civil wars known as the Wars of Religion began and lasted until the promulgation of the Edict of Nantes in 1598. The French occupied with this long internal strife could not give much attention to the discovery of new territories or to the establishment of colonies abroad. But now that peace had come, they could turn their attention to the land reconnoitered by Verrazano and explored by Cartier.

20. He means of course, between the upper tributaries of those rivers. The distance between the headwaters of the Don near Tula and the Oka River is 50 miles; and that between the headwaters of the Khoper and those of the Sura, some twenty miles.

21. "Instructions by Way of advice, " in Travels and Works of Captain John Smith..., E. ArBer, ed. (2d ed. 2 vols., Edinburgh 1910), 1: xxxv.

22. Capt. John Smith... Works, E. Arrer, ed. (2 vols. paged continuously, Birmingham 1884), 420. 
On his first voyage to Canada in 1603 Champlain went up the Saguenay " quelques douze ou quinze lieuês. ) Here he questioned the Indians about the source of the river, and was told that other Indians who lived near the headwaters of the Saguenay " disent qu'ils voyent vne mer qui est salee. Ie tiens que si cela est, que c'est quelque goulfe de ceste mer qui desgorge par la partie du Nort dans les terres; \& de verité il ne peut estre autre chose. ") ${ }^{2} 3$

Champlain's interest in reaching a western sea by means of one of the rivers of Canada is also evidenced by his inquiries at Montreal. Shortly after his arrival at this place he was questioning the Indians about the sources of the St. Lawrence. They gave him a passable description of Lake Ontario, but a very strange description of Niagara Falls: " A la fin du dit lac [Ontario], ils passent vn sault qui est quelque peu éleué, où il y a peu d'eau, laquelle descend. "Beyond this " sault " there is a lake [Erie], and at the end of this lake " vn detroict qui contient deux lieuês de large et va assez auant dans les terres, ) scl., the Detroit River, Lake St. Clair and the St. Clair River. The Indians admitted that they had not seen the end of Lake Huron, the water of which " est trés mauuaise comme celle de la mer. " Reasoning on further information about this lake, Champlain provisionally concluded that Lake Huron was " la mer du Su, estant salee, comme ils disent. " ${ }^{24}$

On redescending the St. Lawrence, Champlain had the good fortune of meeting, at the Island of Orleans, several Algonkin who gave him substantially the same description of the lakes as he had heard in Montreal. "Ils n'y ont esté que fort peu dans ce dernier [lac, i. e., Huron], \& ont ouy dire qu'a la fin dudict lac, il y a vne mer dont ils n'ont veu la fin, ne ouy dire qu'aucun laye veu; mais que la où ils ont esté, l'eau n'est point mauuaise, d'autant qu'ils n'ont point aduancé plus haut. $)^{25}$

Finally, Champlain met an Algonkin " qui auoit fort voyagé dans ledict grand lac [Huron]. " This Indian described the route to Lake Huron via the Ottawa River, Lake Nipissing and the French River,

23. Oeuvres de Champlain, C.-H. LAverdière, ed. (2d ed., 6 vols., paged continuously, Quebec 1870), 86.

24. Ibid., $106 \mathrm{f}$.

25. Ibid., 109. 
and gives the first news of the existence of Lake Superior, " vne mer si grande qu'ils n'en ont point veu la fin, ny ouy dire qu'aucun l'aye veu. Que le soleil se couche à main droite dudict lac. ") Piecing together the information obtained from these three sources, from the Indians at Montreal, at the Island of Orleans and at the Ile aux Lièvres, he says: " selong leur rapport, du sault où nous auons esté [Montreal], il y a iusques à la mer salée, qui peut estre celle du Su, quelques quatre cents lieuês. Sans doubte, suyuant leur rapport, ce ne doibt estre autre chose que la mer du Su, le soleil se couchant où ils disent "; namely, " à main droite du dict lac [Superior]. ") ${ }^{26}$

In 1608, Champlain repeated what he had written five years earlier with regard to the existence of a Sea of the North which he thought opened on the Pacific and which would provide an indirect way of reaching the Sea of the South. "I'ay desiré souuent faire ceste descouuerture, mais ie n'ay peu sans les sauuages, qui n'ont voulu que i'allasses auec eux ny aucuns de mes gens: Toutefois ils me l'ont promis. Ceste descouuerture ne seroit point mauuaise, pour oster beaucoup de personnes qui sont en doubte de ceste mer du Nort, par où l'on tient que les Anglois ont esté en ces dernières années pour trouuer le chemin de la Chine. $)^{27}$

In May 1613, Champlain was again at Sault St. Louis ready to leave " pour descouurir la mer du Nort, sur le rapport qui m'en auoit esté faict. ) This " rapport " had been made to him in Paris in 1612 by " vn nommé Nicolas de Vignau le plus impudent menteur qui se soit veu de long temps, comme la suitte de ce discours le fera voir. ") Vignau had told him that he had seen the Sea of the North, and furthermore " qu'il auoit veu le bris \& fracas d'vn vaisseau Anglois qui s'estoit perdu sur la coste. ") The route from Sault St. Louis to that sea was by way of the Ottawa River, and the round trip could be made in seventeen days. "Cette Nouuelle," says Champlain, " m'auoit fort rejouy, pensant auoir trouué bien près ce que ie cherchois bien loing. ") ${ }^{28} \mathrm{As}$ is well known, when the party reached Allumettes Island, Vignau " me demanda pardon, disant, que tout ce

26. Ibid., $111 \mathrm{f}$.

27. Ibid., 292.

28. Ibid., 440. 
qu'il auoit dict, tant en France qu'en ce païs, touchant ceste mer, estoit faux; qu'il ne l'auoit iamais veue, \& qu'il n'auoit pas esté plus auant que le village de Tessoüat [on Allumettes Lake]; qu'il auoit dict ces choses pour retourner en Canada $"{ }^{2} 9$.

Two years later, in 1615, Champlain was once more on the Ottawa River. He ascended it as far as the Mattawa, where he portaged to Lake Nipissing and descended the French River " iusques au lac Attigouautan "); that is, to Georgian Bay, the eastern arm of Lake Huron. "Ce lac Attigouautan... est fort grand, \& a près de quatre cent lieues de longueur, de l'Orient à l'Occident, et large de cinquante lieuês, \& pour la grande estendue d'iceluy, ie l'ay nommé la Mer Douce. " ${ }^{30}$

The clear result of his voyage to Lake Huron was Champlain's realization that the width of the American Continent was much greater than had been thought previously. Instead of finding bodies of water connected with the Sea of the South, these huge lakes of the West were found to be fresh water seas.

After their return to Canada in 1632, the Jesuit missionaries moved westward and established their headquarters in Huronia. From their various mission centers they evangelized the surrounding country, and the geographical knowledge acquired during their apostolic peregrinations was embodied in Nicolas Sanson's map of 1650 .

One westward expedition which took place between the foundation of the missions in the Huron country and their ruin in 1649, deserves a special mention.

In 1634, Champlain sent Jean Nicolet to " une nation appellée des Gens de mer. " ${ }^{31} \mathrm{He}$ no doubt reasoned that this name meant that these Indians lived on or near the shores of the sea. The habitat of these "gens de mer, " they had learned, was situated about three hundred leagues from Huronia, "tirant vers l'Ouest. " That Champlain believed that this sea was the long sought for Sea of China may be deduced from the garb which Nicolet brought along; namely, "vne

29. Ibid., 465.

30. Ibid., 513.

31. The Jesuit Relations and Allied Documents, R. G. Thw AITEs, ed., hereinafter quoted as JR (73 vols., Cleveland 1896-1901), 23: 276. 
grande robbe de damas de la Chine, toute parsemée de fleurs, \& d'oyseaux de diuerses couleurs. " ${ }^{32}$ The envoy must have expected to find mandarins. Additional information about the purpose of Nicolet's voyage is found in the Relation of 1640. Father Le Jeune wrote:

Le sieur Nicolet qui a le plus auant penetré dedans ces pays si esloignés, m'a asseuré que s'il eust vogué trois iours plus auant sur vn grand fleuue qui sort de ce lac [Green Bay], qu'il auroit trouué la mer, or j'ay de fortes conjectures que c'est la mer qui respond au Nord de la Nouuelle Mexique, \& que de cette mer, on auroit entrée vers le Iapon \& vers la Chine, neantmoins comme on ne sçait pas ou tire ce grand lac, ou cette mer douce, ce seroit vne entreprise genereuse d'aller descouurir ces contrées. ${ }^{33}$

Whatever Nicolet meant by saying that there was a sea at three day's journey from the westernmost point which he reached, or whatever interpretation one puts on his words, the main result of his voyage was that where he expected to find the sea he had found fresh water, and that although he had gone farther west than any one before him, the Sea of the South, like a mirage, kept receding beyond the horizon.

During the years that followed the destruction of the Huron missions, we hear very little about a passage to the Sea of the South. While the colony was fighting for its very existence against the Iroquois, further explorations were out of the question; but beginning with the year 1660, the French once more turned their attention toward the West.

In the third chapter of the Relation of 1659-1660, there is a detailed account of the country west of Lake Superior given to a Jesuit - thought to be Father Druillettes - by an Indian who had spent two years wandering in the West and who said he had gone to the shores of Hudson Bay.

Les Sauuages qui habitent la pointe de ce lac [Superior] la plus éloignée de nous, nous ont donné des lumieres toutes fraisches, \& qui ne déplairont pas aux curieux, touchant le chemin du Iapon, \& de la Chine, dont on a fait tant de recherche. Car nous apprenons de ces peuples I through the intermediary of the above-mentioned Indian], qu'ils treuuent la Mer

32. Ibid., 278.

33. JR, 18: 236. 
de trois costez; du costé du Sud, du costé du Couchant, \& du costé du Nord; de sorte que si cela est, c'est vn grand prejuge \& vn indice bien certain, que ces trois Mers se treuuant ainsi contigues, ne font proprement qu'vne Mer, qui est celle de la Chine; puisque celle du Sud, qui est la mer Pacifique, qu'on connoist assez, estant continuée iusqu'à la mer du Nord, qui est pareillement connue par vne troisième Mer, qui est celle dont on est en peine; on ne peut plus souhaitter, que le traiet dans cette grande mer Occidentale \& Orientale tout ensemble ${ }^{34}$.

In the description of the American Continent which follows the above quotation, the writer combines the information learned from Indians with the representation of North America on Sanson's map of 1650 , and by means of these two sources " discovered " the Northwest passage. According to him, a ship sailing up Hudson Strait in August or September, would then proceed due west through the northern part of Hudson Bay to longitude $270^{\circ}$, where it would turn south, pass through Button Bay to the "Mer Glaciale, " and reach " cette grande mer Occidentale \& Orientale tout ensemble."

But with the French in Canada, this far northern route to the Pacific never attained the popularity of another route whose search almost became an obsession in the ensuing years. As we shall see, the discovery of the Mississippi was really an incident in the search for the route to the Pacific. By the late fifties of the seventeenth century, the French fully realized that the lakes were not the direct water route to the Sea of the South, and although they were likely unaware of Hayes' argument, they reasoned along similar lines:somewhere in the West, there was a divide where a river flowing eastward had its headwaters, and on the other side of that divide there must be a river that led to the Pacific.

I have treated at length how the French learned of the existence of a great western river, and how a new element entered in their conception of North American geography; namely, how they were led to postulate the existence of the Sea of the West, a sea which opened on the Pacific Ocean where the great river probably had its mouth $^{35}$. What follows is a summary of the evolution of their geographical conceptions.

34. JR, 45: 220.

35. Life and Voyages of Louis Jolliet (1645-1700) (Chicago 1947), 20 ff. 
The earliest mention of a great river in the West is found in the Relation of 1659-1660. The same Jesuit who had learned from an Indian " des lumieres toutes fraisches " concerning the country west of lake Superior, says toward the end of his narrative: " Mais a peine me fus-ie rendu à Quebec, que i'y trouuay deux François, qui ne faisoient que d'arriver de ces païs superieurs. " One of these two Frenchmen was Médard Chouart dit des Groseilliers, but we do not know who the other was; what we know is that he was certainly not Pierre-Esprit Radisson. In one of their excursions in the west, the two Frenchmen went six days' journey southwest of Lake Superior, where they saw the remnants of the Huron nation who had been driven to those parts by the Iroquois. In their flight from their enemies, the Hurons " firent heureusement recontre d'vne belle Riuiere, grande, large, profonde, \& comparable disent-ils à notre grand fleuue de S. Laurens. " ${ }^{36} \mathrm{We}$ do not know what this river was, and as far as we are concerned its identity is immaterial, for all that interests us is the appearance of this river of the West.

In the Relation of 1661-1662, Father Lalemant wrote that the Ontôagannha had their villages " le long d'vn beau fleuue qui les porte jusques au grand Lac (C'est ainsi qu'ils nomment la Mer) où ils ont commerce auec des Europeans... Cette Mer est sans doute ou la Baye du S. Esprit dans le Golfe de Mexique en la coste de la Floride, ou bien la Mer Vermeille, sur la coste de la Nouuelle Grenade dans la grande Mer du Sud. " ${ }^{3} 7$

Until 1667, the existence of a great river in the West was known in a general way, but in that year Father Allouez brought back more definite information on western ethnography and geography as well as the name of the great river of the West. Speaking of the Sioux, he says: « Ce sont peuples qui habitent au Couchant d'icy [Chaquamegon Bay, near the western end of Lake Superior], vers la grande riuiere, nommée Messipi. Ils sont à quarante ou cinquante lieuës d'icy ... $n^{38}$ The missionary however, thought that this river " se decharge... en la Mer, vers la Virgin[i]e. ") ${ }^{39}$

36. JR, 45: 234.

37. JR, 47: 146.

38. JR, 51:52.

39. Ibid., 46. 
In 1669, on returning to Quebec from his second western voyage, Allouez asked for additional missionaries. "Le sort, " we read in the Relation of 1668-1669, " est heureusement tombé sur le Pere Claude Dablon, qui a esté envoyé pour estre Superieur de ces Missions d'en haut, nonobstant les grands fruits qu'il faisoit icy, \& la necessité pressente qu'on y avoit de sa personne.) ${ }^{40}$

Of all the Jesuits in seventeenth-century New France, none was more interested than Dablon in the geography of North America. It has been said that " his knowledge of Canadian geography was greater than any of his contemporaries 1$) ;{ }^{41}$ and Frontenac himself publicly declared that Father Dablon is " vne personne qui a la plus grande connoissance de ces lieux là [the West] qu'aucune autre qui soit en ce païs, tant a cause du long sejour qu'il a fait parmy les 8ta8as, que par les memoires et lumieres que luy en ont pu enuoyer ceux de ses peres qui $\mathrm{y}$ ont esté en Mission. " ${ }^{4}$ Besides being interested in the geography of the West, Dablon was also interested in the geography of northern Canada, but his speculations with regard to the latter region bear only indirectly on the subject of this article. ${ }^{43}$

It was to be expected that Dablon would gather all the information he could about the West while working in that region. In the first report which he sent from the West he says

à quelques journées de la Mission de saint François Xavier, qui est la Baye des Puans [Green Bay], se trouve une grande Riviere large d'une lieuë \& davantage, qui venant des quartiers du Nord, coule vers le Sud, \& si loin que les Sauvages qui ont navigé sur cette Riviere, allant chercher des ennemis à combattre, aprés quantité de journées de navigation, n'en ont point trouvé l'embouchure, qui ne peut estre que vers la Mer de la Floride, ou celle de Californie.44

Although Dablon surmised that the great river of the West might possibly have its mouth in the Gulf of California, he did not discard

40. JR, 52: 198.

41. N. M. Crouse, In Quest of the Western Ocean (London 1928), 257.

42. Jugements et délibérations du Conseil Souverain de la Nouvelle-France, 16631710 (6 vols., Quebec 1885-1891), 2: 671.

43. For a biographical sketch of this missionary, see "Claude Dablon, S.J. (1619-1697), " Mid-America, 26 (1944): 91-110.

44. JR, 54: 136. 
the other route to the western sea which had been described in the Relation of 1659-1660; in fact, he even seems to consider the earlier information more reliable.

D'ailleurs, nous sommes aussi assurez par le rapport de quantité d'autres Sauvages, dont les depositions s'accordent tres-bien, qu'à deux cens lieuës de la Mission du saint Esprit [Chequamegon Bay], aux Outaouaks, vers le Couchant, se trouve la Mer de l'Ouest, en laquelle on décend par une autre grande Riviere, qu'on trouve à huict journées de ladite Mission, laquelle Riviere va \& vient bien avant dans les terres; c'est ainsi que les Sauvages expliquent le flux et le reflux de la Mer, \& un d'eux assure y avoir vû quatre Vaisseaux à la voile.

Après ces deux Mers, celle du Sud \& celle de l'Ouest, il ne reste plus que celle du Nord, afin d'en estre environnez de toutes parts; ce qu'étant bien découvert, on en peut tirer ces avantages, qu'il n'est pas impossible de passer de la Mer du Nord à celle du Sud, ou à celle du Couchant: Secondement, que cette Mer du Couchant ne pouvant estre que celle du Iapon, on s'en pourroit faciliter le trajet, \& ensuite le commerce..$^{45}$

The Sea of the West, as distinct from the Sea of the South, makes its appearance for the first time; as we shall see, later writers will elaborate on this concept, a concept which will have a profound influence on theoretical geography during the eighteenth century and on the history of western exploration. Previous to this date, the French talked of the Sea of the South exclusively; but from now on, the Sea of the West with an outlet on the Pacific will gradually become more and more prominent, and will ultimately displace the other altogether. The search for a route to the Pacific will go on, but it will be through the Sea of the West.

In April 1670, Father Marquette, who was in charge of the St. Esprit Mission at La Pointe, sent to Father Dablon what he had learned about the great river of the West, and notified him of his project of descending this river as far as he could in the coming autumn. With regard to the location of its mouth he wrote: " Il est difficile que cette grande Riviere se décharge dans la Virginie; \& nous croyons plûtost qu'elle a son embouchure dans la Califurnie... cette découverte nous donnera une entiere connoissance de la Mer ou du Sud, ou de l'Ouest. ) ${ }^{4} 6$

45. Ibid., 136-138.

46. Ibid., 188-190. 
I have observed ${ }^{4}$ that the last words of the above quotationou de l'Oüest-seem to be an interpolation by Dablon; for there is nothing in the whole paragraph about the Sea of the West, but merely about California, whose shores, Marquette knew, bordered on the Sea of the South. Either Dablon had made his what we read in the Relation of 1659-1660, or he repeated what he himself had written in that Relation; for although Father Lalemant compiled the report in Quebec, the author of the speculation with regard to the existence of a western sea is very likely Father Dablon. The reason for this opinion is because there are many instances of such speculations in the Relations which Dablon either wrote or edited, whereas those in which he had no share contain little theoretical geography.

In the Relation of 1670-1671, where he describes the map of Lake Superior, Dablon again makes mention of the "mer du Couchant " 48 but as will appear presently, his new conception of western geography did not become known in Lower Canada until the following year.

In a memoir sent to Colbert in November 1670, that is, at the time when Dablon was elaborating his theory at Sault Ste Marie, Talon notified the minister that in his instructions of September 3 to St. Lusson, he had given orders " de rechercher soigneusement s'il y a par lacs ou par rivières quelque communication [between the St. Lawrence in the Lake Superior region] avec la mer du sud qui separe ce continent de la Chine. ") ${ }^{4}$ But in the Sault Ste Marie procès-verbal of June 4, 1671, St. Lusson proclaimed that he was taking formal possession " dudit lieu Sainte-Marie-du-Sault, comme aussy des lacs Huron et Supérieur, isle de Caientaton [Manitoulin] et de tous les autres pays, fleuves, lacs et rivières contigues et adjacentes iceluy, tant découverts qu'à découvrir, qui se borne d'un costé aux mers du nord et de l'ouest et de l'autre costé à la mer du sud, comme de toute sa longitude ou profondeur. " ${ }^{50}$

\section{Life and Voyages of Louis Jolliet, 32.}

48. JR, 55: 98.

49. Talon to Colbert, November 10, 1670, Rapport de l'Archiviste de la Province de Québec (RAPQ) pour 1930-1931 (Québec 1931), 136.

50. Memoire sur Mours, Coustumes et Relligion des Sauvages de l'Amerique Septentrionale par Nicolas Perrot, J. Tailhan, ed. (Paris and Leipzig 1864), 294. For the bibliography of this procès-verbal, see Life and Voyages of Louis Jolliet, 15 , note 62 . 
The explicit mention of the Sea of the West as distinct from the Sea of the South is easily explained when we remember that Dablon was present when St. Lusson took formal possession of the West, and this mention may perhaps be taken as an indication that he helped Talon's delegate in drawing the formal procès-verbal.

Shortly after the ceremonie at Sault Ste Marie, Dablon returned to Quebec. On July 12, 1671, he was installed as rector of the Jesuit college there, and superior general for the Jesuit missions in New France. The following passage from Talon's letter to Louis XIV shows first, that the intendant spoke to Dablon, and second, that he echoed the geographical theories of the Jesuit.

Cela s'est fait [the prise de possession of the West by St. Lusson], au recit des peres jesuistes qui ont assisté a cette ceremonie, avec tout l'appareil et l'esclat que le païs a pû souffrir......

On ne croit pas que du lieu ou led. sr de st Lusson a percé il y ait plus de trois cens lieues jusqu'aux extremitez des terres qui bordent la mer Vermeil ou du Sud, les terres qui bordent la mer de louest ne paroissent pas plus esloignées de celles que les François ont descouvertes, selon la supputation qu'on a fait sur le recit des sauvages. Et par les cartes il ne parroist pas qu'il y ait plus de quinze cens lieuës de navigation à faire jusqu'a la tartarie, la chine et le japon..$^{51}$

In the fifth chapter of the third part of the Relation of 1670-1671, Dablon gives a full account of what he had learned about the Mississippi during his sojourn in the West. " Elle semble faire comme une enceinte de tous nos lacs, prenant son origine dans les quartiers du Nord, \& coulant vers le midy, jusqu'à ce qu'elle se décharge dans la mer, que nous jugeons este la Mer Vermeille, ou celle de la Floride, puisqu'on n'a pas de connoissance d'aucunes grandes rivieres vers ces quartiers-là, que de celles qui se déchargent en ces deux Mers. ${ }^{52}$

The description which follows, which we omit because it has no bearing on our subject, is the most detailed and the most accurate description of the Mississippi before its discovery; and except for the location of its mouth, every detail was supplied by the Indians.

Others in New France were also speculating with regard to the location of the mouth of that western river; among them we must mention two Sulpician missionaries, MM. Dollier and Galinée, and

51. Talon to Louis XIV, November 2, 1671, RAPQ, 1931, $157 \mathrm{f}$.

52. JR, 55: 206. 
La Salle. It should be observed, however, that M. Dollier and La Salle speak of the Ohio; and that M. de Galinée's description combines some characteristics of the Mississippi with those of the Ohio.

M. Dollier was certain that the mouth of his great river was not situated on the Alantic coast nor on the coast of the Gulf of Mexico, " ce qui fait croire que [la rivière] dont nous parlons tombe dans une autre mer, de savoir où, j'en laisse le jugement aux plus sçavants. Cependant il est probable qu'elle arrose ces terres fertiles en or et en argent qui sont vers la Nouvelle-Espagne "); in other words, somewhere on the west coast of North America.

In his narrative of the 1669-1670 expedition, M. de Galinée tells how La Salle more or less imposed himself on M. Dollier. When the latter went to Quebec in May 1669, to ask Bishop Laval's leave to go to "les nations que l'on nomme 8 ta8as, " ${ }^{54}$ Courcelle

le pria de vouloir s'unir avec M. de la Salle...... pour faire ensemble le voyage que M. de la Salle avoit prémédité depuis longtemps vers une grande rivière qu'il avoit conceue (selon ce qu'il pensoit avoir appris des sauvages) avoir son cours vers l'Occident, au bout de laquelle après sept ou huit mois de marche,...... les dits sauvages disoient que cette rivière tomboit dans la mer, et cette rivière s'appelle dans la langue des Iroquois Ohio...... L'espérance du castor, mais surtout celle de trouver par icy passage dans la mer Vermeille, où M. de la Salle croyoit que la rivière d'Ohio tomboit, luy firent entreprendre ce voyage pour ne pas laisser à un autre l'honneur de trouver le chemin de la mer du Sud, et par elle celuy de la Chine ${ }^{56}$.

Besides his narrative of the expedition of 1669-1670, Galinee wrote geographical descriptions of Canada. Of these only five pages of notes taken by Michel-Antoine Baudrand are extant ${ }^{57}$. After describing the St. Lawrence from Lake Superior to the Atlantic and saying that the river " peut passer pour un des plus grands du monde puisque son cours est cognu pendant pres de de mille lieues, " Galinée conti-

53. Découvertes et Êtablissements des Français dans l'Ouest et dans le Sud de l'Amerique Septentrionale, P. MARgRY, ed., hereinafter quoted as MARGRY (6 vols., Paris 1876-1888), 1: 181.

54. E.-Z. Massicotte, Montréal sous le régime français (Montreal 1919), 7.

55. A few pages farther down, Galinée says: " M. de la Salle, qui disoit entendre parfaitement les Iroquois... par la connoissance parfaite qu'il avoit de leur langue, ne la sçavoit point du tout et s'engageoit à ce voyage presque à l'estourdie, sans savoir quais où il alloit. ") MARGRY, 1: 117.

56. Ibid., 114.

57. Bibliothèque Nationale (BN), Mss. français, 15451: 11-17. 
nues, "Cepandant touts les Sauvages de la nouvelle france qui ont couru le paīs et dont on s'est informé conviennent entre eux que le Fleuve de St Laurent n'est pas le plus considerable dont elle soit arroussee ils en cognoissent un autre que les Iroquois appellent Ohio et les Algonkins et Outaouacs Missi sipi. "He then gives a description of this river by Indians who had descended it to its mouth, and ends by saying: "Il est difficile de conclure ou elle se iette car apparement elle ne se rend pas dans la mer du Nord [the Atlantic Ocean] ou on ne trouve aucune riviere qui aye l'apparence de la riviere Ohio, elle ne se iette pas non plus dans la baye de Hudson, selon que les sauvages disent qu'il fait chaud a son embouchure, ainsy il semble quelle se peut descharger dans la mer Vermeille qui luy sert d'embouchure. ")

On the eve of the Jolliet-Marquette expedition, the geographical knowledge of the country adjacent to Canada possessed by the French may be summarized as follows: They had learned from the Indians that there was a sea in the north, but they were not certain whether this sea was Hudson Bay or some other body of water; from their maps they knew that the Gulf of Mexico was south of New France, and that the Vermilion Sea which opened on the Pacific was to the southwest; they had also learned from the Indians that not very far from Green Bay there was a mighty river flowing in a southerly direction, but they did not know where this river had its mouth, whether in the Gulf of Mexico or in the Gulf of California. When actual exploration proved in both cases that the information from the Indians was correct; namely, there was a sea in the north, and there was a great river west of Green Bay, the French had no reason for doubting that there was a sea in the west, for its existence had repeatedly been vouched for by other Indians.

Father Albanel solved the northern puzzle in 1671; and in July 1674, Jolliet brought to Quebec the solution of the southern problem. Two years earlier Jolliet had been commissioned by Talon to search for a water route to the Sea of the South, " et sur tout, " wrote Dablon, " de scauoir dans quelle mer s'alloit decharger la grande Riuiere dont les Sauvages font tant de recit, et qui est a 500 lieües d'icy [,] au dela des outaoüax. " ${ }^{58}$ Although the Gulf of Mexico is given as an alterna-

58. Relation de la decouverte de la Mer du Sud... par le Pere Dablon ", in Mid-America, 26 (1944): 317. 
tive when the French speculated as to where the great river had its mouth, they fervently hoped that it emptied into the Gulf of California.

Accompanied by Father Marquette and five companions, Jolliet descended the Mississippi to a village situated some twenty miles north of the mouth of the Arkansas River. In his interview with Dablon in the last days of July 1674, Jolliet gave the reasons why he was certain that the Mississippi emptied into the Gulf of Mexico. This news greatly disappointed the Jesuit as can be seen from the letter containing the account of this interview:

La troisiesme remarque est que comme il eut esté tres souhaitable que le terme de cette découverte eust esté la mer vermeille, qui eut donné en mesme temps entrée dans la mer du Japon et de la chine, aussy ne doit on pas desesperer de venir a bout de cette autre decouuerte de la mer du couchant, par le moyen de Missisipi, par ce que en remontant au Norouest, par la riuiree qui si decharge par le 38 degré [the Missouri] ...... peut estre arriuera ton a quelque lac qui a sa decharge vers le couchant, ce que l'on recherche, et ce qui est d'autant plus a esperer, que toutes ces terres sont remplies de lacs et coupées de riuieres, qui donnent de merueilleuses communications à ces pais. ${ }^{59}$

Jolliet says the same thing in the dedicatory letter to Frontenac, which he inscribed on the map drawn from memory after his return to Quebec; with the difference that the explorer is more emphatic than Dablon in saying that the Vermilion sea could be reached by ascending one of the western tributaries of the Mississippi: "Par une de ces grandes riuieres qui viennent de l'Ouest et se dechargent dans la Riu. Buade on trouvera passage pour entrer dans La mer vermeille. " And Frontenac who had also heard Jolliet wrote to Colbert: « Il [Jolliet]... croit que par les rivières qui, du côté de l'ouest, tombent dans la grande rivière qu'il a trouvée... on trouverait des communications d'eaux qui mèneraient à la Mer Vermeille et de la Californie. ") 60

The French had thus solved two long standing geographical problems, but the solution of the third, the discovery of a water route to the western sea which they had so much at heart seemed as remote as ever. However, it was their quest for that western sea that had spurred

59. Ibid., $321 \mathrm{f}$.

60. Frontenac to Colbert, November 14, 1674, RAPQ, 1927, 77. 
them on, and had been the determining factor in the discovery of the Mississippi, a magnificent achievement that compensated for the failure to disclose a new route to China and the Far East. One may wonder whether the French would have continued the search had they known the extent of the vast region intervening between the Mississippi and the Pacific, and had they known of the huge mountain range which lay between them and the sea.

Shortly after Jolliet's return with the news that the Missouri might be the water route to the Pacific, La Salle arrived at Quebec. We know that, in November 1674, he went to France with Jacques Barrois, Frontenac's secretary, who was bringing Jolliet's map to Paris; we also know that La Salle saw this map on which the dedicatory letter was inscribed; and it is unlikely that he was unaware of what Frontenac had written to Colbert about the possibility of reaching the Vermilion Sea by the Missouri River. This being so, two questions present themselves. First: Did La Salle inquire about this route when he was on the Mississippi eight years later? Le Clercq says he did. The second question is: Did La Salle ever again try to find a route to the Pacific after the fiasco of 1669 ? According to Hennepin, the discovery of this route was uppermost in La Salles' mind from 1675 on. We will examine the pertinent passages in the works of these two writers and ascertain what part La Salle played in the search for a transcontinental water route to the East.

We read in the Premier Etablissement de la Foy dans la Nouvelle France:

Les glaces qui derivoient en cet endroit [mouth of the Illinois River] sur le Fleuve Colbert, nous y arresterent jusques au treziéme du même mois [February, 1682] que nous en partîmes, \& nous trouvâmes à six lieues plus bas la riviere des Ozages qui vient de l'Oüest \& est bien aussi forte que le Fleuve Colbert dans lequel elle se décharge, \& qui en est tellement troublé, que depuis l'embouchure de cette riviere l'eau n'est quasi pas potable, les Sauvages nous assurerent que cette riviere estoit formée de quantité d'autres, \& qu'on la remonte dix ou douze journées de chemin jusques à une montagne d'où elles tirent leur source, \& qu'au de là de cette montagne c'est la Mer oû l'on voit de grands Navires, qu'elle est peuplée d'une multitude de grands Villages de plusieurs Nations differentes, qu'il y a des terres et des prairies, grande chasse de Bœufs \& de Castors. ${ }^{61}$

61. C. Le ClencQ, Premier Etablissement de la Foy dans la Nouvelle France (2 vols. Paris 1691), 2: $236 \mathrm{f}$. 
I have observed more than once that the two chapters of Le Clercq's book in which La Salle's adventures from 1680 to 1682 are narrated, allegedly by Father Membré, were not written by the latter, but that they were the handiwork of the editor of the Premier Etablissement de la Foy, whoever this editor may have been. The peculiar thing about the passage under examination is that in no other account of the descent of the Mississippi by La Salle in 1682, do we find any mention of a " riviere des Ozages, " or of a mountain, or of a sea.

In his letter dated Michilimackinac, July 23, 1682, Tonti says: " Ayant navigé le 13 [February] Nous trouvames a 6 lieues sur la main droite une grande riviere qui vient de l'Ouest appellée la riviere Missoury. " 6 2 And in 1684, he wrote:

Nous descendismes le fleuve et nous trouvasmes à six lieues, sur la main droite une rivière qui tombe dans le fleuve Colbert, laquelle vient de l'ouest et paroist aussy grande et aussy considerable que la grande riviere, selon le rapport des Sauvages. Elle s'appelle Emissourita, abondante en peuples. Il y a mesme des villages de Sauvages, lesquels se servent de chevaux pour aller en guerre et pour transporter la chair des bœufs qu'ils tuent à la guerre. 1$)^{63}$

This shows that the explorers questioned the Indians with regard to the Missouri, and if they had been told that headwaters were only ten or twelve days' journey away, and that the sea could be seen from the top of the mountain where those headwaters were located, Tonti would have mentioned these facts.

Nicolas de la Salle, also a member of the expedition speaks of the Missouri as follows: " Enfin on descendit le Missisipi. Le premier jour, on alla cabaner a six lieues du costé droit, proche de l'embouchure d'une riviere qui tombe dans le Mississipi, et qui la rend fort trouble et bourbeuse. Elle se nomme la riviere des Missouris. Cette rivière vient du nord-ouest. Elle est fort peuplée, à ce que disent les sauvages. Les Panis sont sur cette rivière fort loing de son embouchure. "164 Father Membré, the alleged author of the account in Le Clercq omits

62. BN, Clairambault, 1016: 166.

63. MARGRY, 1: 595. - "We descended this river and found six leagues below, on the right, a great river which comes from the west. There are numerous nations above. We slept at its mouth. " Tonti's memoir of 1690 in L. P. KELLOGG, ed. Early Narratives of the Northwest (New York 1917), 297.

64. MARGRY, 1: $549 \mathrm{f}$. 
the Missouri altogether and says not a word about a " riviere des Ozages " in his letter of June 3, 1682: "Après $y$ [at the mouth of the Illinois River] avoir demeuré quelques jours, retenus par les glaces qui en dérivoient du haut, nous en partimes le (sic) et vinsmes le lendemain dans un village abondonné ") 65 ; the Tamaroa village, six leagues below the mouth of the Missouri. Finally, Claude Bernou who wrote a relation of the voyage of 1682 merely says: "Ils trouvèrent sur la main droite, une grande rivière qui vient de l'ouest, appelée la rivière de Missoury. ") 66

In view of all these texts, one is justified in saying that the "riviere des Ozages " passage is one of the numerous senseless interpolations found throughout the second volume of the Premier Etablissement de la Foy.

A passage similar to that in Le Clercq is found in a " Memoire Sur la Louisiane, " dated March 1717, and written in Mobile by M. Lemaire, a priest of the Paris Séminaire des Missions Etrangères. ${ }^{67}$ In a section entitled "Digression sur la mer de l'Ouest, " he says:

Il m'est tombé entre les mains un manuscrit de deffunt Mr La Salle où j'ay trouvé que dans les recherches qu'il fit par les terres du Mississipy, des sauvages des environs des Ilinois luy dirent que la riviere des osages avoit sa source a deux journées de la mer de l'Ouest, et qu'il ne falloit que 15 à 20 jours pour la remonter, ce qui donneroit la mer de l'Oúest à 221 lieuës de l'embouchure de la riviere des osages dans le Missouri [i.e., Mississippi]. Mais de deux choses l'une ou ces sauvages en imposèrent à Mr La Salle, ou celuy-cy a pris le Missouri pour la riviere des osages. Je crois d'autant plus aisement ce dernier que dans le manuscrit il n'est pas parlé du Missouri, lequel n'auroit pas été omis sil neut esté pris pour la riviere des osages. ${ }^{68}$

What M. Lemaire says bears some resemblance to what is attributed to Father Membré in Le Clercq, with the difference that the latter does not give the name of the sea in the west, and that the distance from the mouth of the " riviere des osages " to that sea is only half the distance mentioned by M. Lemaire.

65. MARgRy, 2: 207. La Metairie makes no mention of the Missouri nor of the Osage River in the récit preceding the procès-verbal of April 9, 1682. Ibid., 186-193.

66. "La Salle's Expedition of 1682, " Mid-America, 22 (1940): 28.

67. M. Lemaire's memoir is discussed in the second part of this article.

68. BN, Mss. français, 12105: 8. 
We have no means of knowing what this manuscript might have been, nor in what circumstances it fell into M. Lemaire's hands; nor how he ascertained that it was a manuscript of " deffunt Mr La Salle.» What we know is that some of the statements cannot be reconciled with what we learn from La Salle's writings. For instance, his autograph letter of post September 29, 1680, is the only one which contains information about the Mississippi derived from " des sauvages des environs des Illinois "; and La Salle makes no mention of the " riviere des osages, " nor of the distance from its mouth to the sea of the West. ${ }^{9} 9$

Contrary to what M. Lemaire thought, La Salle did not mistake the Osage River for the Missouri. As was shown above, the members of the 1682 expedition use a variant of the word " Missouri " when they mention the name of the great western tributary of the Mississippi, and La Salle himself does not refer to it by any other name. In his extant writings, the Missouri is mentioned twice, both times in a fragment of an autograph letter written at Starved Rock in March 1683.

The first mention occurs in passage in which he criticizes Jolliet's description of the Chicago portage. It would be easier, he says, to transport goods from Starved Rock to Lake Michigan by land than by water,

en se servant de chevaux qu'il est aisé d'y avoir, y en ayant beaucoup chez les Sauvages appelez Pana, Pancassa, Manrhout, Gatea, Panimaha et Pasosé, un peu esloignez, à la vérité, vers le couchant, mais avec qui on peut avoir une communication très-facile, tant par la rivière des Missourites, qui tombe dans le fleuve Colbert, si ce n'en est pas la principale branche, tousjours navigable l'espace de plus de quatre cents lieues vers l'Ouest, ou par terre, tout le pays qui est entre ces peuples et le fleuve Colbert estant descouvert et comme une vaste campagne par où on peut aisément les emmener par terre ${ }^{70}$.

The second mention of the Missouri occurs toward the end of the same fragment, where La Salle describes his voyage to the sea in 1682. Below the Illinois River, he wrote, the Mississippi flows

toujours le long de ces rochers à gauche et de cette campagne à droite, jusqu'à ce qu'il rencontre la rivière des Missourites, qui tombe dans le fleuve

69. M ARGRY, 2: $52 \mathrm{ff}$.

70. Ibid., 168. 
Colbert dix lieues au-dessous la rivière des Islinois et vient de l'ouest, si ce n'est pas la plus considérable branche de ce mesme fleuve tant pour sa profondeur que pour sa largeur, la quantité de ses eaux, les grandes rivières qu'elle reçoit, le grand nombre de nations qui l'habitent et la bon té du pays qu'elle arrose ${ }^{71}$.

In neither case does La Salle call the Missouri " riviere des osages " nor does he speak of a sea which can be seen from the top of the mountain where the feeders of the Missouri have their headwaters; nor that these feeders have their sources at two days' journey from the Sea of the West. He makes no mention of a mountain " à dix ou douze journées " from its mouth, nor " qu'il ne falloit que 15 à 20 jours pour la remonter, " but states that the Missouri is navigable for more than 400 leagues. This last item of information must have been supplied by those Indians of whom he speaks, and if they had mentioned a sea, La Salle would have recorded this fact, for it could only be the Sea of the South which he was so anxious to find in 1669 .

We may now take up the second question; namely, was the discovery of a route to the Pacific uppermost in La Salle's thoughts after 1675 ? Hennepin's repeated assertions will be examined in chronological order.

On April 11, 1680, Michel Accault, Antoine Auguelle and Father Hennepin were taken prisoner by a band of Sioux, they were despoiled by these Indians and brought to their country. Shortly after his arrival at the Sioux village, writes Hennepin,

Le fils d'Aquipaguetin qui m'appeloit son frere, portoit en parade nostre Chasube de brocart sur son dos tout nud, dans laquelle il avoit enveloppe les os d'un mort, ...... \& apres que ces Sauvages eurent fait servir cette Chasube d'ornement à couvrir les os de leurs morts, dans leurs plus grandes ceremonies, ils en firent present a des Peuples de leurs Alliez, scituez à l'Ouest à environ cinq cens lieues de leur Païs, qui estoient venus chez eux en Ambassade, \& qui avoit dansé le Calumet. ${ }^{72}$

Except for a few variants the above passage is reproduced without additions in the Nouvelle Decouverte ${ }^{73}$. Later in this book Hennepin

71. Ibid., 180.

72. L. Hennepin, Description de la Louisiane (Paris 1683), 243.

73. L. Hennepin, Nouvelle Decouverte d'un tres grand pays Situé dans l'Amérique, entre le Nouveau Mexique et La Mer Glaciale (Utrecht 1697), 352. 
refers once more to these ambassadors. Besides affording a typical example of Hennepin's technique, the parallel passages quoted below show how the story vastly improved in the fourteen years which intervened between the publication of the Description de la Louisiane and that of the Nouvelle Decouverte.

\section{Description de la Louisiane}

Durant nostre sejour chez les Issati ou Nadouessiou nous vimes des Sauvages qui estoient venus en ambassade d'environ 500. lieues du côté de l'Ouest,

ils nous apprirent que les Assenipovalacs n'estoient qu'à 7. ou 8. journees de nous du costé du Nord Est; et tous les autres peuples que l'on connoit à l'Ouest \& au Nord Ouest,

\section{Nouvelle Decouverte}

Dans la suite du temps on a reconnu que ce Détroit d'Anien étoit imaginaire. Plusieurs personnes distinguées par leur grand savoir sont de ce sentiment. Je puis joindre ici une preuve de cette vérité à toutes les leurs. C'est, que pendant que j'étois parmi les Issati $\&$ les Nadoủessans, il y vint quatre Sauvages en Ambassade chez ces Peuples. Ils venoient de plus de 500 lieúes du côté de l'Ouest. Ils nous firent entendre par les Interpretes qu'ils avoient marché quatre Lunes. C'est ainsi qu'ils appellent les mois. Ils ajoûtoient que leur pays étoit à l'Ouest, \& que nous étions au Levant à légard de leurs Contrées; qu'ils avoient toûjours marché pendant ce temps là sans s'arrêter que pour dormir, \& pour tuer à la Chasse de quoi subsiter. Ils nous assuroient, qu'il n'y avoient point de Détroit d'Anien, \& qu'assurément ils n'avoient rencontré ni passé dans leur route aucun grand Lac, e'est le terme, dont les Sauvages se servent pour representer la Mer, ni aucun bras de Mer.

Ils nous certifièrent de plus, que la Nation des Assenipouaalacs, dont le Lac est marqué sur la Carte, \& qui sont au Nord-Est des Issati, n'étoient qu'à six ou sept journées de nous: que toutes les Nations de leur connoissance, qui sont à l'Ouest, \& au Nord-Ouest, n'ont aucun grand Lac aux environs de leurs vastes Pays, mais seulement des Riviéres, qui décendent du Nord au travers des Nations voisines de leurs Confins du côté du grand Lac, e'est à dire de la Mer dans a langue des Sauvages: que là il y a des Esprits, \& des Pygmées ou petits hommes, par ce qu'en effet ils sont d'une tres petite stature, comme les peuples les plus avancez les en avoient assurez, \& 
habitent dans des Prairies \& Campagnes immenses, où il y a quantité de bœufs sauvages, \& de pelleteries,

quelquefois ils sont obligez de faire du feu avec de la fiente de bœuf, faute de bois ${ }^{74}$. que toutes les Nations qui sont situées au delà de leurs pays, \& qui sont les plus proches d'eux, habitent dans des prairies, \& dans des campagnes immenses, ou on trouve quantité de Taureaux Sauvages, de Castors, qui sont plus gris que ceux du Nord, dont le poil tire plus sur le noir, \& plusieurs autres bestes fauves, qui fournissent de tres belles pelleteries.

Les quatre Sauvages susdits, qui étoient venus en Ambassade, nous ont encore assurez, qu'il y a fort peu de forests dans les pays, par lesquels ils avoient passé pour se rendre au lieu, ou nous étions, \& qu'ils étoient par fois obligez de faire du feu avec de la fiente de Taureaux Sauvages pouir cuire de la viande dans les pots de terre, dont ils se servent, n'en connoissant point d'autres ${ }^{75}$.

"Toutes les circonstances, que nous venons de rapporter, ") he goes on to say, prove that there is no Anian Strait. ${ }^{76}$ But why this should be deduced from " all these circumstances" is not quite clear, for had not the ambassadors told him in so many words that " il n'y avoit point de Détroit d'Anien "? Hennepin refrained from saying where these Indians had learned that certain maps showed this geographical feature, and unless they had seen such maps and made a comparison with the actual geography of that part of North America, how could the Indians assert that " il n'y avoit point de Détroit d'Anien " ? As a proof of the non-existence of this strait, he continues, " je m'offre ici de tout mon cœur de retourner avec tels Vaisseaux, que Sa Majesté Britannique, et les Hauts \& Puissans Seigneurs des Etats Generaux des Provinces unies trouveront à propos d'y envoier pour en faire l'entiere Découverte. )

When he reached the end of this chapter, Hennepin must have realized that merely to prove the non-existence of the Strait of Anian would be of little interest to "Sa Majeste Britannique, ) or to the "Hauts \& Puissans Seigneurs "; something better, the route to the East, for instance, was evidently called for. "Quelques efforts que

74. Description de la Louisiane, 259.

75. Nouvelle Decouverte, 369-371.

76. Cf. G. E. NunN, Origin of the Strait of Anian Concept (Philadelphia 1929). 
les Anglois \& les Hollandois, les peuples du monde qui voyagent le plus sur l'Ocean, ont pu faire pour aller à la Chine \& au Japon par la Mer Glaciale, ils n'ont pu y réussir jusqu'à présent. Mais par le moien de ma Découverte j'espère, Dieu aidant, que toute l'Europe verra, qu'on pourra trouver un passage commode pour s'y rendre. On pourra en effet se transporter par des Riviéres capables de porter de gros Vaisseaux dans la Mer pacificque, \& de la il sera aisé d'aller à la Chine \& au Japon sans passer sous la ligne Equinoctiale. ") 77

The context shows that when Hennepin speaks of his " Découverte ") as the route to China and Japan, he means the country through which he had traveled in 1680. It is regrettable that he did not indicate how the "gros Vaisseaux) would reach the upper Mississippi. Reaching the East " par le moien de ma Découverte » must have dawned on him quite recently, for if he had thought of it in 1682, when he returned to France after his " great voyage " to the Sioux country, why did he not speak of it to the authorities in Paris? After all, the French were more interested than anyone else in finding just such a route through Hennepin's " Découverte. " And when he himself arrived in Canada in 1675, the year following Jolliet's return from his unsuccessful search for the route to the Sea of the South, Hennepin must have heard about it. As a matter of fact, to hear him, the route to the Sea of the South had been in La Salle's and in his own mind ever since 1675 .

We learn this from the Nouveau Voyage, Hennepin's third literary venture, which appeared at Utrecht in 1698, the year following the publication of the Nouvelle Decouverte. After giving his version of the origin of the name of Lachine, near Montreal, he continues: " toutes les esperances qui faisoient la passion dominante de cet excellent Voiageur [La Salle], \& les mines, pendant nôtre sejour au Fort de Frontenac, ne roulerent que sur ce grand dessein de nous rendre à la Mer pacifique contiguée aux terres de nôtre Louisiane. ") ${ }^{78}$ Many authors, he says, are of the opinion that Japan is not an island, but " que les terres de ce grand Empire aboutissent au grand Continent de nôtre Louisiane; j'ai joint au Chapitre 37 [i.e., 57] de mon Volume precedent [the Nouvelle Decouverte] une preuve de cette verité. ")

77. Nouvelle Decouverte, 373.

78. L. DE Hennepin, Nouveau Voyage d'un Pais plus grand que l'Europe (Utrecht 1698), preface. 
This " proof " is the coming of the ambassadors to the Sioux country, "qui m'ont asseuré par truchement, qu'il n'y avoit point de Detroit d'Anien, comme on a cru jusques à present, ce qui nous fait croire que les vastes Contrées de l'Amerique Septentrionale, sont contiguées des terres du Japon, \& qu'elles ne sont point separées par aucunes Mers, ni de Detroit d'Anien pretendu. " We are again told of the failure of the English and the Dutch, " les plus grands Navigateurs de l'Ocean, " to find a northwest passage to China and Japan, but if he were allowed to go back to " nos vastes Découvertes, nous trouverons infailliblement un passage commode, pour nous rendre des terres de nôtre Louisiane, dans la Mer pacifique, par des Rivieres, qui portent des gros Vaisseaux, situées au dela du fameux Fleuve de Meschasipi. ॥

The opening paragraphs of the first chapter of the Nouveau Voyage give many details concerning the intentions and plans of La Salle.

J'ai demeuré prés de trois ans en qualité de Missionnaire avec le Sieur Robert Cavelier de la Salle dans le Fort de Katarokoüy ou de Frontenac, dont il étoit Gouverneur \& proprietaire. Pendant ce temps nous nous occupions souvent ensemble à lire les Voiages de Jean Ponce de Leon, de Pamphile Narvaëz, de Christofle Colomb, de Ferdinand Soto, \& de plusieurs autres grands voyageurs, afin de nous preparer mieux à la Découverte, que nous avions dessein de faire. ${ }^{79}$

All told, Hennepin was eighteenth months with La Salle at Fort Frontenac. It is hard to believe that there was such a " bibliothèque des voyages ") in this outpost of the wilderness, but even if Herrera's Historia General de las Indias (Ponce de León), Cabeza de Vaca's Relación (Narvaez), and Las Casas' Historia de las Indias (Columbus) had been there, one does not see how the reading of these books were of much use as a preparation for the discovery of a transcontinental route to the Pacific. The only book which we know La Salle had with him is Richelet's French adaptation of Garcilaso de la Vega's Historia del Adelantado Hernando de Soto; and La Salle had this book after his voyage to France in 1678; that is, after the " trois ans " during which " nous nous occupions souvent ensemble à lire, " at Fort Frontenac.

Notre premiere pensée, lorsque nous étions au Fort de Frontenac, avoit été de trouver, s'il estoit possible, le passage que l'on a cherché depuis

79. Ibid., 2. 
si longtemps à la Mer du Sud, sans passer la Ligne Equinoctiale. Quoique le Fleuve Mechasipi n'y conduise pas, cependant le Sieur de la Salle avoit tant de lumieres et de courage, qu'il espéroit de le trouver par ses soins. Je ne doute pas, qu'il n'eust reüssi, si Dieu lui eust conservé la vie. Mais il fut massacré dans cette recherche, \& il semble que Dieu a permis que je survécusse audit Sieur de la Salle, afin que je fournisse au public le moien de trouver le chemin de la Chine \& du Japon par le moien de ma Découverte. Et en effet si sa Majesté Britannique, ou les Hauts \& Puissans Seigneurs des Etats generaux veullent bien que j'accompagne ceux, qu'ils envoieront pour achever de chercher ce chemin abbregé, je suis moralement assurê, que nous en viendrons à bout, s'il plaist à Dieu, avant la fin de ce Siècle ) ; that is, in less than two years' time.

Before examining the main fact in this and in the previous paragraphs from which we have quoted, a few of the above statements should be disposed of. First, La Salle was not killed while looking for the route to China and Japan. Second, Hennepin's repeated offers to accompany Englishmen or Dutchmen in their search for a short cut to the East “ par le moien de ma Découverte, " is just as genuine as his willingness to guide the English to the mouth of the Mississippi, to his Louisiana any time they were ready to undertake this voyage. When it looked as though the English were going to take him at his word, Hennepin hastily departed from the dominions of " Sa Majeste Britannique. " 80

All the grand projects attributed to La Salle in the preface and in the first chapter of the Nouveau Voyage were imagined by Hennepin in later years. Indeed, if La Salle and Hennepin had planned in 16751678 the discovery of the route to China and Japan, which in the Nouveau Voyage is said to be " plus considerable que [toutes] les Découvertes que l'on a faites jusques à present, ") why is it that there is not a word about such a discovery in the Description de la Louisiane published fifteen years earlier? Since it cannot be because the route to the Pacific was considered of less moment in 1683 , it can only be because La Salle was not interested in finding such a route, and consequently made no plans for its discovery.

After 1669, La Salle never again sought to find a " chemin racourci de la Chine et du Japon. " Between 1678, the year when he really began his career as an explorer, and 1684, when he went to France and 77 ff.

80. " Hennepin's Voyage to the Gulf of Mexico 1680, " Mid-A merica, 21 (1939): 
became a part to the mad scheme for the conquest of New Biscay, La Salle was interested in only one thing;-in the trade in the Great Lakes country and in the Mississippi Valley. He is constantly speaking of this trade in his letters written between those two dates, and the single mention of the "Mer du Sud " found therein refers not to the Pacific but to the Gulf of Mexico. ${ }^{81}$ In all his writings there is only one incidental mention of the Sea of the West: " D'autres, appelés Chaa [Cheyenne], qui demeurent au haut de la grande rivière [the Mississippi], arrivèrent [at Fort Crèvecœur] le 24 Février [1680] et nous invitèrent à aller chez eux, où ils disent avoir une grande quantité de castors et de pelleteries, et estre voisins de la mer de l'Ouest. ") 82 According to Hennepin, after La Salle found out that the Mississippi was not the route to the East, he still hoped " de trouver. . . le passage à la Mer du Sud. " Now La Salle's plans for the future, outlined in a letter written six months after his voyage to the sea, ${ }^{83}$ contain no reference whatsoever to any further search for a route to the Sea of the South. And, we may ask, how did Hennepin know what La Salle's plans were after 1682? The last time he saw La Salle was on February 29, 1680 , two years before the voyage to the Gulf.

A discussion of Hennepin's lucubrations was necessary for two reasons. First, because we wished to ascertain whether after 1669, La Salle ever again had the intention of finding a route to the Pacific, as asserted in the Nouvelle Decouverte and in the Nouveau Voyage; and second, because of the use made of some of these texts, and of others to be quoted below, by the author of an eighteenth century memoir on the Sea of the West.

In a letter to Seignelay written after March 1682, ${ }^{4}$ Duluth begins by answering accusations which had been levelled at him. He then narrates his various voyages in the northwest during which he discovered the Sioux country, and explains how he learned that Hennepin,

81. Margry, 2: 52.

82. Ibid., 54 .

83. Margry 2: 288-301.

84. The date is inferred from a reference to Father Hennepin a de présent au couvent de Saint-Germain. "The missionary had arrived in Paris at the end of February or at the beginning of March, 1682. Cf. H. Lemay, "Le Père Louis Hennepin, Récollet, à Paris 1682, "Nos Cahiers, 3 (1938): 115. 
Accault and Auguelle were prisoners of the Sioux and how he immediately set out to rescue them. After much palavering with these Indians, Duluth told Father Hennepin and his two companions that they must accompany him to Green Bay,

Quoyque mon dessein fut de pousser jusques à la mer du costé de l'ouest-nord-ouest, qui est celle que l'on croit estre la mer Vermeille, d'où les Sauvages, qui estoient allez en guerre de ce costé-là donnèrent du sel à trois François, que j'avois envoyez à la descouverte, et lesquels m'apportèrent dudit sel, m'ayant rapporté que les Sauvages leur avoient dit qu'il n'y avoient que vingt journées, d'où ils estoient pour trouver le grand Lac, dont l'eau ne vaut rien à boire. C'est ce qui me fait croire qu'il ne seroit pas tout à fait difficile de la trouver, si l'on vouloit permettre d'y aller. ${ }^{85}$

Although Duluth specifically mentions the Vermilion Sea, the large body of water situated north-northwest of the Sioux countryif this direction can be trusted-is Lake Winnipeg. On the other hand, this direction is an indication that he is speaking of a sea other than the Gulf of California, for everybody knew that the Vermilion Sea was situated to the southwest of the Lake Superior region. Duluth's vagueness makes it impossible to know how far and in what direction the three Frenchmen went, nor does he give any indication as to the point of departure of the twenty days' journey to the " grand Lac dont l'eau ne vaut rien à boire ${ }^{86}$. ")

In another letter, also undated, but posterior to the one from which we have just quoted, Duluth tells Seignelay that while he was in the Sioux country: " Il a eu cognoissance de la mer Vermeille par la relation de ces Sauvages, qui luy en ont mesme donné du sel, et laquelle n'est distante des villages desdits Nadouessious que de vingt journées par terre. " ${ }^{87}$ Here he specifies that the sea in question is twenty days' journey from the Sioux villages and not, as he had previously written, from the westernmost point where the three Frenchmen had gone; another variant is where he says that he himself instead of the three Frenchmen was given the salt brought by the Indians.

85. MARgry, 6: 24. The letter is in AC, $\mathrm{C} 11 \mathrm{E}, 16: 7-9 \mathrm{v} ; \mathrm{H}_{\text {ARRISSE gives an exact }}$ reproduction of it in his Notes pour servir... 177-181.

86. J. B. BReBNER thinks that this is a « reference to what may have been Great Salt Lake. ") The Explorers of North America 1492-1806 (New York 1937), 352.

87. MARgRY, 6: 36, from AC, C 11E, 16: 6-6v. 
The purpose of this second letter was to obtain permission to establish a post in the Sioux country, so that these Indians " voyans une manière d'establissement, luy donneront tous les secours nécessaires pour faire sa descouverte aux costes de la Mer de l'Ouest, nommée Mer Vermeille. "Duluth makes no distinction between the two seas, although by this time, those interested in a water route to the Far East had made it clear that the Vermilion Sea was different from the Sea of the West.

In a memoir sent to Paris by Vaudreuil and Bégon in 1716, we find a description of a route up the Kaministikwa to Dog Lake, Rainy Lake and Lake of the Woods; " du bout de ce lac il se trouve une rivière qui tombe dans la Mer du Ouest, suivant le rapport des Sauvages. " The memoir then continues:

Les Sauvages Assiniboiles ont voulu mener à la Mer de l'Ouest [Jacques] de Noyon, voyageur, il y a environ vingt-huit ans [1688]. Il avoit hiverné à l'entrée du Lac des Christinaux, [Lake of the Woods], sur la rivière Ouchichiq [Winnipeg] qui conduit au Lac des Assiniboiles [Lake Winnipegl et de là à la Mer du Ouest, et luy proposèrent au petit printemps d'aller avec eux à la Mer du Ouest, où les Sauvages allèrent en guerre au nombre d'environ cent hommes contre une nation, dont les hommes n'ont environ que 3 pieds $1 / 2$ à 4 pieds de haut et fort trapus. Le sieur Jêrémye ${ }^{88}$ en a vu deux à la baye d'Hudson, que ces Sauvages y ont amenés, lesquels ils avoient pris au bord de la mer, qui ressemblent à d'autres Sauvages, à l'exception qu'ils ont les cheveux crépus. Ces Sauvages [Assiniboin] leur ont aussi rapporté qu'il y avoit des villes et des bourgades fortifiées; que les hommes alloient à cheval et les femmes en croupe; que ces hommes sont blanes et barbus. Les mesmes Sauvages rapportent avoir vu des navires, qu'ils ont tire du canon, et si ledit de Noyon avoit voulu faire ce voyage, les Sauvages luy avoient promis qu'il seroit de retour en cinq mois, luy ayant dit que le rivière estoit très belle et qu'après avoir trouvé le flux et le reflux, ils sont trois jours à descendre à la mer.

Que trois jours auparavant d'estre au flux et au reflux de la mer ils traversent les terres pour gagner une ville, qu'ils disent estre fort 6tendue et dont l'enceinte est de pierre. Ils disent aussi avoir entendu tirer des coups de canon et vu des vaisseaux au bas de cette rivière, où ils vont en guerre contre ces petits hommes, mais ils n'osent s'approcher de ces villes et bour-

88. Nicolas Jérémie had gone to Hudson Bay with Iberville in 1694. After the taking of Port Nelson, he remained in this post until 1714, when Hudson Bay was ceded to England. The Relation written after his retrun and alluded to in the text, belongs to a later phase of the search for the Sea of the West. 
gades et ne font aucun commerce avec les gens habitués dans ces pays; ils ont pris des moutons, dont de Noyon en a eu deux peaux ${ }^{89}$.

The above description contains details which are obviously imaginary, such as Indians with kinky hair, ships firing guns, fortified towns by the sea. There is one detail, however, with which we are already familiar, the stature of the western Indians. Ten years after the voyage of Jacques de Noyon, Hennepin wrote that the " ambassadors ") who came to the Sioux country while he was there, had mentioned "Pygmées ou petits hommes " living near the sea; and to make his meaning clear, he added the reason why they are called " petits hommes, " saying " par ce qu'en effet ils sont d'une tres petite stature). It may be that these Indians had gone to Hudson Bay, where they could have seen ships, gun firing, and bearded men, and had inserted in their account of such a voyage legendary native lore concerning western Indian tribes.

In the seventeenth century, the French had thought that Hudson Bay might be the route to the Sea of the West. This possibility had not been lost sight of, as we learn from an addition to the same memoir of Vaudreuil and Bégon. M. d'Iberville, they wrote,

estant à la baye d'Hudson, envoya le nommé Renaudot pour tascher de découvrir s'il n'y avoit point un passage pour aller à la mer de l'Ouest. Il trouva un détroit, dans lequel il navigua 12 lieues, mais ce dessein n'eut pas d'autre suite.

Il avoit envie de faire cette découverte par la baye d'Hudson sur le rapport que les Sauvages luy en avoient fait, et sur les mémoires des Anglois, qui s'étoient trouvés au port Nelson dans le temps de sa prise en 1694 Cette découverte ne pourroit se faire qu'en faisant hyverner des bastimens au fort Bourbon, afin de profiter de la navigation, qui est fort courte, d'autant qu'il faudroit aller par les 80 degrés Nord [ ?], et, suivant le rapport de quelques Sauvages, jusqu'aux 90 degrés [!!!], ce qui fait croire qu'il y a presque de l'impossibilité d'aller par cet endroit à la mer de l'Ouest.90

At the time when Iberville was making his unsuccessful attempt in the north, Antoine Laumet, better known under his self-granted noble alias Antoine de Lamothe Cadillac, was writing at Michilima-

89. MARGRY 6: $496 \mathrm{f}$. Margry partially modernized and corrected the spelling of this memoir which is in $\mathrm{AC}, \mathrm{C} 11 \mathrm{E}, 16: 13-16$.

90. Margry, 6: $499 \mathrm{f}$. 
ckinac, where he was commandant, one of this interminable memoirs. ${ }^{91} \mathrm{~A}$ passage in the last section of this memoir treats of the Sea of the West.

Il y a aussi chez cette nation [Sioux [ une rivière connue dans la prof ondeur des terres jusqu'à 1,000 lieues. Elle n'est point rapide et porteroit barque partout ...... Sa source n'est pas encore connue. La rivière coule et descend du costé de l'ouest et vient se joirdre à celle du Mississipi, qui va à la mer du Sud. Ma pensée est qu'on pourroit, par cette rivière, descouvrir la Mer de l'Ouest.)

Cadillac then repeats Edward Hayes' argument: at Chicago, tributaries of the Mississippi interlock with rivers emptying into Lake Michigan and so into the St. Lawrence, which flows into the Atlantic.

Ce qui prouve assez clairement qu'il n'y a rien de si aisé dans le monde, que d'avoir la communication des deux mers par les lacs et rivières, en traversant la profondeur des terres jusqu'à 12 ou 1,500 lieues, et en prenant la rivière de Saint-Pierre [Minnesota] qui se joint à celle du Missisipi, dont la source est au Sud-Ouest à 48 degrez de latitude et à 276 de longitude, et qui passe aux Sioux, on peut la suivre en courant à l'Ouest jusqu'à 1,000 lieues, si bien que si la rivière de Saint-Pierre, aussi grande et aussi belle que celle de Mississipi, prend sa source de quelque lac, situé et assis sur une élévation de terre, qui donne deux pentes, comme il arrive en tous les autres, il est évident qu'il faut que cette rivière aille tomber dans la mer de l'Ouest ou dans quelque autre mer, car il est clair que ce ne peut estre dans la mer de l'Est, et il est très difficile de concevoir que ce puisse estre dans la mer du Nord.

A century later, by ascending a tributary of the Mississippi, Lewis and Clark reached a mountain and found near the headwaters of this tributary a river flowing toward the west and emptying into the Pacific. This tributary, however, was not the Minnesota, but the Missouri. We do not know what led Cadillac to say that barks - that is,

91. Relation du Sieur De lamotte Cadillac capitaine en pied, aiant une compagnie de la Marine en Canada, cy deuant commandant De Missilimakinak et autres postes Éloignés ou il a été pendant trois années. The manuscript which formerly belonged to Margry is now in the E. E. Ayer Collection of the Newberry Library, Chicago. Margry printed it in volume 5: 75-132, of his compilation. The document is not in the handwriting of Cadillac, but in that of a copyist who finished writing it on July 21, 1718, the date at the end of the manuscript. Margry says (5: 679), " Je l'ai vu citer... et toujours comme de Lamothe Cadillac. " That Cadillac wrote a Relation while he was at Michilimackinac is clear from two 1696 autograph letters of his, one to Pontchartrain (BN, Clairambault, 882: 146v), and the other to Lagny (ibid., 137). 
decked ships-could ascend the Minnesota one thousand leagues; ${ }^{22}$ he must have misunderstood what the Indians told him, for at this date, no Frenchmen had as yet sailed up the river in a bark, and Cadillac had not come within 400 miles of the mouth of the Minnesota. cors:

Quant à la source de la rivière du Mississipi, nous venons de dire qu'elle est à 48 degrez de latitude et à 276 de longitude. Il y a apparence qu'elle prend naissance dans quelque lac, qui forme une autre rivière, allant au nord se descharger dans le grand lac des Assiniboels [Winnipeg], qui forme des rivières sans fin, lesquelles vont se dégorger vers le fort Nelson et dans les autres grandes bayes. Ce lac est appelé par les Sauvages le grandpère de tous les lacs, voulant dire par cette expression, qu'il est incomparablement plus grand que tous les autres. Les Assiniboels rapportent qu'après avoir traversé par les lacs et les rivières pendant cent jours de marche, en allant vers le soleil couchant, on trouve la mer salée, après quoi ils disent qu'il n'y a plus de terre. Cela estant, ce ne pourroit estre que la mer de l'Ouest. ${ }^{93}$

We do not know how Cadillac learned the position of the sources of the Mississippi, the earliest map on which they are marked at the position mentioned above is Delisle's map of 1703, several years after the writing of this memoir. The distance between the country of the Assiniboin and the Pacific is 1,500 miles in a straight line, but much longer " par les lacs et les rivières, " as he says. Since the Indians traveled an average of twenty-five miles a day when on a long march, they could have reached the Pacific in one hundred days. What is surprising is that the Indians questioned by the French never mentioned the Rocky Mountains; yet, if they had actually gone to the coast, they had to cross this huge mountain range before reaching the sea.

Ever since the early days of the colony, the French had been keenly interested in finding a route to the Pacific, an interest which may be said to have been one of the determining factors in their North American explorations. At times, conditions in Canada forced them to postpone their search, but from the days of Champlain they never abandoned the hope of finding a water route to the Pacific; they resumed their quest whenever they heard new and apparently trustworthy information about the West. As the years went by, the sea in the

92. The total length of its course from Big Stone Lake to the Mississippi is about 450 miles, or 200 leagues.

93. MARGRY, 5: 125-127. 
West, like a mirage, receded beyond the horizon and the route to it increased in length. Champlain first thought that Lake Huron was the Sea of the South; later that it lay west of Lake Superior. Nicolet reported that, at three days' journey from Green Bay, there was a sea, which Father Le Jeune conjectured to be the Sea of China. After the exploration of Lake Superior, when it became apparent that the lakes were not the direct route to the Sea of the South, the French began to look for a river that led to it. For a while it seemed as though the Mississippi was this river, but when they discovered that it emptied into the Gulf of Mexico, they looked for a river coming from the west, convinced that near its headwaters would be found those of another river flowing westward. Meanwhile Dablon had made public his hypothesis that somewhere in the west there was a sort of North American Mediterranean, with its outlet on the Pacific. This new geographical conception was all the more readily accepted because if there should be such a sea, the route to the Pacific would be that much shortened. But with each new item of information heard from the Indians, even this sea receded father west: Assiniboin Indians told De Noyon that the journey to the Sea of the West would take two and a half months, and other Indians informed Cadillac that it could be reached after one hundred days' travel.

Cadillac's memoir is the last seventeenth century document which mentions the Sea of the West. He probably brought it to Paris in $1699^{94}$. France was then at the eve of the War of the Spanish Succession and had greater worries than the solution of an American geographical problem. But, as we shall see, the interest in finding the Sea of the West, and the search for a route to it will be resumed as soon as the country is again at peace.

Loyola University

Jean Delanglez, s.j.

Chicago.

94. Cadillac left Quebec in October 1698. In this letter of 1696 to Pontchartrain, he says: "J'aurai, Monseigneur, l'honneur de vous la [his Relation] présenter si mes amis en sont d'avis, lorsque je serai en europe. " BN, Clairambault, 882: 146v 